\title{
THE LEGAL PROTECTION OF MARINE ECOSYSTEM FROM CIGARETTE BUTTS POLLUTION IN INDONESIA
}

\author{
Nasrullah* \\ Abdul Haseeb Ansari** \\ Adis Putri Nelaniken***
}

\begin{abstract}
Indonesia is recognized as a country with high potential in maritime resources. However, Indonesia is also known as the second-largest contributor to plastic waste in the ocean. It is estimated that Indonesia contributes around 200,000 tonnes of plastic disposals. The highest pollutant of the plastic product was found to be cigarette butts. The trillions of cigarette butts generate chemical contamination the ocean waters. Chemicals that leach from the cigarette butts are extremely toxic to the aquatic life in the ocean. The marine pollution caused by this contamination was never seriously noticed, even though the huge number of cigarette butts were found in the sea. A grave concern should be shown on the impacts of the cigarette butts to the ocean. The objective of this article is to elaborate on Indonesian law dealing with the issue the cigarette butt pollution contaminating the oceans of Indonesia.This article is the result of normative research which analyzes exiting statutes and cases that aims at protecting the marine ecosystem from the cigarette filter disposal. This research attempts to analyze the existing laws and regulations in Indonesia on the protection of the marine ecosystem from toxic and hazardous wastes, especially from cigarette butt waste disposal. The results of this study show that to date there is no specific regulation dealing with tobacco waste product disposals. Accordingly, the government is suggested to enact a set of specific and effective regulations pertaining to tobacco waste products as done by some developed countries or states such as Singapore and Australia, so that marine pollution caused by cigarette butts could be prevented.
\end{abstract}

* Faculty of Law, Universitas Muhammadiyah Yogyakarta, Indonesia, corresponding author, email: nasrullah@umy.ac.id.

** Researcher on Environmental Law, Malaysia.

*** Faculty of Law, Universitas Muhammadiyah Yogyakarta, Indonesia. Email: adisputri24@gmail.com. 
Keywords: Cigarette butt, legal protection, marine pollution, toxic and hazardous wastes.

\title{
PERLINDUNGAN EKOSISTEM LAUT DARI PENCEMARAN PUNTUNG ROKOK DI INDONESIA
}

\begin{abstract}
ABSTRAK
Indonesia dikenali sebagai negara yang mempunyai potensi yang tinggi sumber maritime.Walaubagaiamanapun, Indonesia juga terkenal sebagai penyumbang kedua terbesar dunia sisa plastik ke laut. Indonesia dianggarkan menyumbang 200,000 ton pembuangan plastik. Bahan pencemaran yang tertinggi sisa plastik yang dijumpai adalah puntung rokok. Beberapa trillion puntung rokok mampu menyebabkan pencemaran perairan laut. Bahan kimia yang dihasilkan oleh puntung rokok adalah sangat beracun terhadap kehidupan akuatik di dalam laut. Pencemaran laut disebabkan oleh pencemaran tidak pernah di beri perhatian serius, walaupun begitu banyak sisa puntung rokok telah dijumpai di laut. Keperihatinan yang lebih perlu ditunjukkan bagi mengawal kesan buruk puntung rokok terhadap hidupan laut. Objektif makalah ini ialah bagi menghuraikan undang-undang Indonesia bagi mengatasi masalah ini. Makalah ini terhasil dari penyelidikan normatif yang terhasil dari analisa statut dan kes bagi memelihara ekosistem daripada dirosakkan oleh puntung rokok dan pembuangan penapis rokok. Penyelidikan ini cuba untuk menganalisa undang-undang sedia ada di Indonesia bagi memelihara ekosistem laut dari pembuangan merbahaya terutamanya yang datang dari pembuangan sisa puntung rokok. Hasil kajian ini menunjukkan tiada peraturan bagi mengatasi masalah yang disebabkan oleh pembuangan produk sisa tembakau. Oleh sebab itu, kerajaan disarankan untuk menggubal undang-undang yang spesifik dan berkesan bagi menangani masalah pembuangan sisa tembakau yang dilakukan oleh negara-negara maju seperti Singapura dan Australia, agar pencemaran laut yang turut disebabkan oleh pembuangan sisa puntung rokok dapat di atasi.
\end{abstract}

Kata kunci: sisa puntung rokok, perlindungan undang-undang, pencemaran laut, sisa beracun dan merbahaya. 


\section{INTRODUCTION}

Development does not only bring several positive effects and allows the continuity of human life and the environment but, at the same time, it also brings numerous threats vis a vis the environment. ${ }^{1}$ One serious adverse effect of development is the generation of a large number of waste products as a result of various activities carried out by humans, such as industrial wastes or even household wastes. Since the introduction of plastic as a material used by humans in various forms, natural conditions of the environment have changed significantly. Over 30 to 40 years, the environment is facing a serious problem due to the deleterious impacts of plastic wastes, which are released particularly into the world's ocean. Marine litter or waste is a collection of garbage not only in the oceans but also on the beaches. Surprisingly, marine debris is one of the most common litter problems for the sea. ${ }^{2}$ Among the most dangerous marine debris includes cigarette butts. Cigarette butt pollution is one of the most common marine pollution around the world, including Indonesia. This does not only occur as a result of smokers on the beach but unconsciously this waste also results from garbage on land which is thrown away through the river and ends up in the ocean.

The world buys roughly around 6.5 trillion cigarettes each year, which is approximately 18 billion cigarette every day. A major part of these cigarettes have plastic filters made up of cellulose acetate, which is highly toxic. They are first tossed into the environment, end up in the streams and ultimately makes it way to the sea. Unknown and unnoticeable to many, they severely pollute the marine environment with harmful plastics loaded with nicotine and heavy metals. ${ }^{3}$ Physically, a cigarette butt has a small form if compared to other types landfills, so people seldom realize the significant impact behind its small shape. The nature of materials is similar to plastics; in that this waste is also difficult to degrade. Annually, around 4.5 trillion of

Otto Soemarwoto, Ekologi, Lingkungan Hidup dan Pembangunan (Jakarta: Djambatan, 1994), 150-152.

2 R. R. Churchill and A. V. Lowe, The Law of the Sea (Manchester: Manchester University Press, 1988), 242.

3 "What Is the World' Most Littered Plastic Items? Cigarette Butts," National Geographic, accessed July 15, 2020, https://www.nationalgeographic.com/environment/2019/08/cigarettesstory-of-plastic/. 
cigarette butts are discarded worldwide. ${ }^{4}$ On 25 th November 2019,Viva.co.id released a news entitled, "Indonesia Penyumbang Limbah Puntung Rokok Terbesar Kedua di Dunia" (Indonesia is the World's Second Largest Contributor of Cigarette Butts) written by Adinda Permatasari and Sumiyati. The news quoted the result of research by Jenna Jambeck, a researcher at the University of Georgia and concluded that Indonesia is the second country in the world that contributed to marine debris after China. There are at least 187.2 million tons of garbage from Indonesia in the sea and most of them are cigarette butts. $^{5}$

Furthermore, cigarette butts have now attracted the world's attention. From trillions of cigarettes produced worldwide every year, most of them are fabricated with filters made from cellulose acetate. The material is a form of plastic that can take a decade or even more to decompose. Thomas Novotny, a professor from San Diego State University, said:

It's pretty clear there is no health benefit from filters. They are just a marketing tool. And they make it easier for people to smoke. It is also a major contaminant, with all that plastic waste. It seems like a no-brainer to me that we can't continue to allow this. ${ }^{6}$

In Indonesia, marine pollution caused by non-biodegradable cigarette butts that damaged Indonesia's marine ecosystems has gained much attention recently. The number of cigarette butts found in the ocean is

4 Novotny TE, Lum K, Smith E, Wang V, Barnes R “Cigarette Butts and the Case for an Environmental Policy on Hazardous Cigarette Waste," Int J Environ Res Public Health 6, no. 5 (2009): 1691-1705, https://doi.org/10.3390/ijerph6051691.

5 Adinda Permatasari and Sumiyati, "Indonesia Penyumbang Limbah Puntung Rokok Terbesar Kedua di Dunia,“ viva.co.id, accessed June 7, 2021, https://www.viva.co.id/gaya-hidup/kesehatan-intim/1189364indonesia-penyumbang-limbah-puntung-rokok-terbesar-kedua-didunia?page $=3 \&$ utm_medium $=$.

6 James Rainey, "Plastic Straw Ban? Cigarette Butts are the Single Greatest Source of Ocean Trash," NBC News, accessed July 27, 2020, https://www.nbcnews.com/news/us-news/plastic-straw-ban-cigarettebutts-are-single-greatest-source-ocean-n903661. 
undeniable because based on the Tobacco Atlas 2015, 66 percent of men in Indonesia are active smokers. ${ }^{7}$

A recent study shows that cigarettes with filters is a type of tobacco waste that leaves the most detrimental effect to the environment. ${ }^{8}$ The impact of toxic materials contained in cigarette butts actively destroy the marine ecosystem. ${ }^{9}$ Experts suggests that in order to control this problem, there is a an urgent need to improve tobacco waste product regulations by using the framework of extended producer responsibility.

Although the attention of cigarette butt pollution in the ocean has increased recently, the policymakers are inattentive on the issue of tobacco waste products. ${ }^{10}$ Indonesia still has no valid and specific regulations concerning tobacco waste products. Also, lack of public awareness is making the problem much more serious. To make matters worse, aside from weak law enforcement over tobacco waste products, Indonesia seems to allow cigarette companies to shrug off responsibility on tobacco waste products, especially in the case of filters contained in a cigarette butt. ${ }^{11}$ The existing literature focuses on the situations in high-income countries, while this research focuses on Indonesia. It is apparent that the issue of cigarette butt pollution is now a crucial issue that needs to be solved. ${ }^{12}$ It is hoped that this research

7 Anonymous, "Jumlah Perokok di Indonesia Terbanyak Kalahlan Rusia dan China," Tribun News, accessed June 25, 2020, https://makassar.tribunnews.com/2016/05/25/jumlah-perokok-diindonesia-terbanyak-di-dunia-kalahkan-rusia-dan-china.

8 T.E Novotny et al, "Tobacco and Cigarette Butt Consumption in Humans and Animals," Tob. Control 20, (2011): 17-20, http://dx.doi.org/10.1136/tc.2011.043489.

99 Ibid.

10 Eike, "Why Plastic is the New Fish, and It's Basically Because We're All Flippin' Lackadaisical about It," Core Sea, accessed July 1, 2020, https://coresea.com/plastic-new-fish/.

11 Amanda Kistler, "Plastic Industry Awareness of the Ocean Plastics Problem," CIEL, accessed July 5, 2020, https://www.ciel.org/news/plastics-industry-knew/.

12 Clifton Curtis et al, "Tobacco Industry Responsibility for Butts: A Model Tobacco Waste Act". Tob. Control 26, (2017): 113-117, http://dx.doi.org/10.1136/tobaccocontrol-2015-052737. 
may introduce a different regulatory approach to solve the problem of cigarette butts disposal into the marine ecosystem in Indonesia.

\section{STATEMENT OF PROBLEM}

In Indonesia, like many third world countries of South Asia and SouthEast Asia, middle class and lower middle class people, especially the laboures, smoke a sizably large part of cigarettes with plastic butts. ${ }^{13}$ This leads directly to the problem of marine pollution caused by cigarette butts in Indonesia. There is a lack of competent law to deal with the situation and lack of consciousness among the people as well. And whatever law the country has to deal with the situation is poorly enforced. In fact, it is a neglected area of marine pollution in the country. There is therefore a necessity to investigate as to how the Indonesian law regulates the issue of cigarette butts as a toxic and hazardous waste for the protection of the marine ecosystem in Indonesia. In order to make the law competent and effective, certain rules need to be suggested which are already in place in some highincome countries.

\section{RESEARCH METHOD}

This research adopts a normative approach ${ }^{14}$ which relies on an analysis of existing provisions relating to the protection of the marine ecosystem from the cigarette butts disposal. This research attempts to explain the existing regulations in the Indonesian legal system on obligations and responsibilities that may exist on cigarette manufacturers. Aside from that analysis of the types of existing forms

13 Carmela Protano, et al, "Impact of Electronic Alternatives to Tobacco Cigarettes on Indoor Air Particular Matters Levels", International Journal of Environmental Research and Public Health, Vol. 17, 2020, pp. 29472957; Robert. K. Jackler, et al, "Global Marketing of IQOS: The Philip Morris Campaign to Popularize "Heat-Not-Burn Tobacco", Released on: February 21, 2020, IQOS_Paper_2-21-2020F.pdf; Wojciech Baran, et al, "The influence of waste from electronic cigarettes, conventional cigarettes and heat-not-burn tobacco products on microorganisms, Journal of Hazardous Materials, Vol 384, 2020, 121594-121605.

14 Soerjono Soekanto and Sri Mamudji, Penelitian Hukum Normatif: Suatu Tinjauan Singkat (Jakarta: PT. Raja Grafindo Persada, 2007), 12. 
of protection against cigarette butt waste pollution on the marine environment. In doing so, reliance is made on existing literature. Focus is made on reading and analyzing legislations, legal dictionaries, textbooks, journal articles, cases and legal encyclopedias. ${ }^{15}$

\section{LITERATURE REVIEW}

A review of existing literature was conducted and the results are presented herewith in the categories provided in this section.

\section{Marine Ecosystem Protection from Cigarette Butts Disposal}

According to Josse G.B. Derraik in his study, plastic debris is the extensive reason why marine species are being harmed or killed. Although many are already endangered by other anthropogenic activities. ${ }^{16}$ Currently, the world is confronted with pollution problems that cause damage to the marine ecosystem. Many plastic debris produced by humans that pollutes the ocean. Human daily activities cannot be avoided from plastic waste. Plastic waste is nonbiodegradable, as is cigarette butt disposal.

Furthermore, Richard L Barnes in his research found that cigarette butts consist of three components that are very harmful to the environment, especially for the marine ecosystem. ${ }^{17}$ Cigarette butts that pollutes the marine ecosystem does not only endanger marine life, but also human life. The toxin that leaches into the water will contaminate the fish and it is also possible to end up in the human body once humans consume the fish.

Another study shows that cigarette butts contain some carcinogenic chemicals similar to those secreted from pesticides. Moreover, nicotine produced by tobacco comprises the main cause of

15 Mike McConville and Wing Hong Chui, Research Methods for Law (Edinburgh: Edinburgh University Press, 2012), 13.

16 G.B Derraik Josse, "The Pollution of The Marine Environment by Plastic Debris: A Review". Elsevier Marine Pollution Bulletin 44 (2002): 845852, https://doi.org/10.1016/S0025-326X(02)00220-5.

17 Richard L Barnes, "Regulating the Disposal of Cigarette Butts as Toxic Hazardous Waste". Tobacco Control 20 (2011): 145-148, https://dx.doi.org/10.1136\%2Ftc.2010.041301. 
avertible deaths in wide-reaching. Unfortunately, these cigarette butts are in general unconsciously and inevitably discharged in the trillions into the global environment every year. Cigarette filters do not only damage human health but also the earth. Although there is a warning not to throw away any cigarette butts, it is not yet effective in reducing the environmental impact caused by this waste. Chemicals contained in cigarettes damage aquatic organisms, although cigarette butts are thrown away on the side of the road, this garbage will be carried away by streams which will ultimately damage ocean life. ${ }^{18}$

The researches above reveal that the longevity of plastics in the marine ecosystem should be taken as a grave concern at both the national and international level. Cigarette butts and filters are not biodegradable because of the existence of the plastic inside the filter.

A majority of researchers explain the impact of cigarette butt pollution globally, and only few of them explains the concerns from the legal perspective. In this study, the focus is on the legal aspects of Indonesian law that protect Indonesia's marine ecosystem from cigarette butt pollution.

\section{Extended Producer Responsibility Principle}

Thomas Novotny's research shows that the Extended Producer Responsibility (EPR) principle constitutes one of the best principles that can be used for managing the environmental effects of tobacco waste products. The EPR principle is an environmental policy protection strategy to achieve environmental goals from reducing the total ecological impact of a product, by making the product manufacturer responsible for the entire product life cycle and especially for product recovery, recycling and final disposal. ${ }^{19}$

In addition, The EPR uses the Polluter Pays Principle from the Rio Declaration. the use of this principle is in order to extend the

18 Cheryl G Healton et al, "Butt Really? The Environmental Impact of Cigarettes," Tobacco Control $20 \quad$ (2011): 11 , http://dx.doi.org/10.1136/tc.2011.043729.

19 Clifton Curtis et.al, "Extended Producer Responsibility and Product Stewardship for Tobacco Product Waste". International Journal of Waste Resources 4, no. 10, (2014): 4172, https://dx.doi.org/10.4172\%2F22525211.1000157. 
responsibility for a product through the product's lifecycle. In the United States of America, the EPR is known as an extended product responsibility. It means that the responsibility for the products does not only belong to the producer. The producer is not the one categorized as a responsible party, but there is also the packaging manufacturer, the consumer and the retailer which could also be said as the responsible parties. ${ }^{20}$ Companies commonly avoid the implementation of the EPR principle, instead they prefer the product stewardship approach as it is often chosen by the policymakers. Some companies would be benefit from adopting this approach. This is especially so for companies that produce products which have post-consumption waste. They eagerly support this approach, because they would be absolved from taking responsibility for the waste that results from using their products.

Some researchers in the west has already put serious attention on the need for implementing the EPR principle in their domestic law. However, in Indonesia, this principle is not yet recognized as an essential principle that must be implemented in some regulations. In this research, the authors elaborate the idea of implementing the EPR principle in Indonesian Environmental Law, especially on managing the cigarette butt disposal.

\section{THE IMPACT OF CIGARETTE BUTTS AS TOXIC AND HAZARDOUS WASTE IN INDONESIA'S MARINE ECOSYSTEM.}

Cigarette filters began to be used in 1950 as scientific researches found that cigarettes can cause cancer and other serious illnesses. By adding filters to the cigarette butt, it is expected that smokers would not be directly affected by exposure to poisons contained in the cigarettes. ${ }^{21}$

20 Nicole C. Kibert, "Extended Producer Responsibility: A Tool for Achieving Sustainable," Journal of Land Use \& Environmental Law 19 (2004): 503 -

523 , https://www.researchgate.net/publication/265158179_Extended_produce r_responsibility_A_tool_for_achieving_sustainable_development.

21 US Department of Health and Human Services, "The Health Consequences of Smoking: the Changing Cigarette-A Report of the Surgeon General DHHS Publication No. (PHS) 81- 50156. Department of Health and Human Services," Public Health Service, (USA: Rockville, MA 1981). 
However, the results of the research by Prof. Novotny shows that adding cigarette filters is useless and is only used as a marketing tool and there is no effect on health. ${ }^{22}$

Cigarette butt contains cellulose acetate, this material is photodegradable, but it is not bio-degradable. When cigarette butts containing cellulose acetate is exposed to ultraviolet rays, the filter will split into small pieces. The filter in the cigarette butt is a place where the residues of combustion process are trapped, because a single cigarette butt may produce tar and some heavy metals, such as cadmium, mercury etc. ${ }^{23}$ The residues are toxin which is very destructive to the environment. ${ }^{24}$ The toxins contained in it will never disappear and it becomes diluted in water or soil. The process of diluting the material will automatically damage the ecosystem, especially in the ocean. ${ }^{25}$

Cigarette butt waste does not only damage the marine ecosystem. Recent study shows that under certain conditions, coastal marine sediment can also run into depletion due to the substance contained in the cigarette butt filter. ${ }^{26}$ Cigarette butts are categorized as toxic and hazardous waste. Toxic and hazardous waste is every waste made from hazardous and/ or toxic materials which are due to the nature and/ or the concentration of and/ or the amount of the materials

22 James Rainey, loc.cit.

23 Wajhul Qamar et al, "Cigarette Waste: Assessment of Hazard to the Environment and Health in Riyadh City," Saudi Journal of Biological Sciences 27 (2019): 3, https://doi.org/10.1016/j.sjbs.2019.12.002.

24 Halenur Kurmus and Abbas Mohajerani, "The Toxicity and Valorization Options of Cigarette Butts", Waste Management 104, (2020): 105, https://doi.org/10.1016/j.wasman.2020.01.011.

25 Juergen Puls, "Degradation of Cellulose Acetate-based Materials: A Review," Journal of Polymer and the Environement 19, no. 1 (2011): 152165, https://link.springer.com/article/10.1007/s10924-010-0258-0.

26 Marianne Quéméneur et al, "Impact of Cigarette Butts on Microbial Diversity and Dissolved Trace Metals in Coastal Marine Sediment," Estuarine, Coastal and Shelf Science 240 (2020): 17, https://www.researchgate.net/deref/http $\% 3 \mathrm{~A} \% 2 \mathrm{~F} \% 2 \mathrm{Fdx}$.doi.org\%2F10. 1016\%2Fj.ecss.2020.106785. 
directly or indirectly damage the environment and/or pollute, and/or harm the environment. ${ }^{27}$

Although a single cigarette butt may not leave a serious impact on the ecosystem, a serious impact must emerge when billions of pieces of cigarettes butts make their way into the sea, polluting the marine ecosystem. The toxic materials used to produce cigarette filters will damage the Indonesian marine ecosystem, for instance, some bivalve organisms like mollusc, oyster, and others will be at risk due to the toxins leached from cigarette butt. ${ }^{28}$ Indonesia is placed at the top rank in Southeast Asia for the number of active smokers. This is also indicated by the large number of cigarettes produced in 2018 reaching approximately 338 billion filtered cigarettes. Referring to the data, the high number of cigarettes filtered production in Indonesia will also contribute to the high possibility of marine pollution polluted by cigarette butts. ${ }^{29}$

The impact of hazardous cellulose acetate causes an increase in the level of environmental pollution globally. About 680,000 tons of cellulose acetate is used by the company to produce filtered cigarettes. The number of filtered cigarettes production will increase in 2025. It is predicted that the consumption of filtered cigarettes will increase significantly to nine trillion. Approximately, 1.69 billion pounds of butts will end up as litter worldwide per year ${ }^{30}$. Moreover, one cigarette butt which contain toxins can contaminate 1000 litres of water. ${ }^{31}$ So,

27 Setiyono, "Dasar Hukum Pengelolaan Limbah B3", Jurnal Teknologi Lingkungan 2, no. 1 (Januari 2001): 72-77.

28 Montalvão et al, "Cigarette Butt Leachate as a Risk Factor to The Health of Freshwater Bivalve", Chemosphere 234 (2019): 379-387, https://doi.org/10.1016/j.chemosphere.2019.06.100.

29 Fiki Ariyanti, "Produksi Rokok Diprediksi Turun Jadi 321,9 Miliar Batang di 2018," Liputan 6, September 18, 2017, https://www.liputan6.com/bisnis/read/3099580/produksi-rokokdiprediksi-turun-jadi-3219-miliar-batang-di-2018.

30 Carlozo, L. R, "Cigarettes:1.7 Billion Pounds of Trash," Chicago Tribune, accessed June 18, 2020, https://www.organicconsumers.org/news/cigarettes-17-billion-poundstrash.

31 Amy L Roder Green et al, "Littered Cigarette Butts as A Source of Nicotine in Urban Waters", Journal of Hydrology 519 (2014): 12, 10.1016/j.jhydrol.2014.05.046. 
if there are millions of cigarette butts that are not taken care of, the oceans will continue to be polluted, which will also cause damage to the marine ecosystem and may have an impact on humans being.

Marine debris is not only garbage that is generated directly from the oceans but also caused by waste generated by existing activities on the land entering the ocean, it is called as land-based activities. For example, improper handling of waste management, modest waste management by the company, smokers who throw cigarette butts on the beach which eventually carried by the waves into the ocean. So, land-based activities can also produce marine debris. The United Nations Environment Programme (UNEP) defines marine debris as "any persistent, manufactured, or processed solid material discarded, disposed of, or abandoned in the marine and coastal environment." 32

Wastes that pollute the sea can cause environmental damage and endanger the population in the sea. In January 2018, it was reported that plastic waste in the sea was eaten by anchovy, and a survey found that 28 percent of the fish in the fish market consumed plastic. This does not rule out the possibility that other marine biota will accidentally eat plastic waste too because they think that plastic is their food. ${ }^{33}$ Moreover, the impact of marine debris will also damage the coral reef ecosystems in the sea. Cigarette butts and other plastic waste that covers the ocean area will prevent coral reefs from getting sunlight that is useful for their survival. Among 2.5 million hectares of coral reefs in the Indonesian sea, only 37 percent of the area are in a quite good condition. ${ }^{34}$

According to Ocean Conservancy's International Coastal Cleanup (ICC), the most frequently found debris in the ocean is cigarette butt waste, which is $1,863,838$ items of cigarette butt waste. Meanwhile, straws are ranked 7th with 409,087 items found in the

32 UNEP, "Marine Litter", accessed June 7, 2020, https://www.unenvironment.org/explore-topics/oceans-seas/what-wedo/working-regional-seas/marine-litter.

33 Annisa Febriana Ayub, "Laut Indonesia dan Ancaman Sampah Plastik," Detik News, accessed June 6, 2020, https://news.detik.com/kolom/d4056107/laut-indonesia-dan-ancaman-sampah-plastik.

34 Badan Pusat Statistik, Statistics of Marine and Coastal Resources (2016). 
ocean. ${ }^{35}$ Comparing with other wastes, cigarette butt is the most dangerous one because cigarette butts are it acutely toxic for both marine life and freshwater fish species. It is occurred due to the hazardousness of the cigarette butt's leachates. A smoked filter is not as poisonous as some leachates from smoked cigarette butts combined with the tobacco residuesbecause they were significantly more toxic to the ecosystem. Surprisingly, even unsmoked filters revealed a small level of toxicity. ${ }^{36}$

The latest research shows that Indonesia is the second-largest polluter in the world. With approximately 1.29 million metric tons per year, plastic waste is disposed into the ocean. A cigarette butt is one of the litters which potentially threat the underwater ecosystem in Indonesia. Toxic ingredients contained in cigarette butt poison fish and will eventually poison human who eats the fish. So, cigarette but is not only harmful to the ecosystem but also human being. ${ }^{37}$

The study also estimated that global loss income caused by sea debris reached $\$ 13$ billion. These losses include ship repairs, cleaning costs, and decreased tourism revenues. Besides, sea debris is also at risk for human health. This fact can hurt and involve people, and also creates a danger of navigation. ${ }^{38}$

Fish consumption in Indonesia reached more than $40 \mathrm{~kg}$ per capita in 2017, and the number has increased from the previous year. ${ }^{39}$ According to Debris Free Oceans, plastic waste ingested by marine biota can threaten humans who consume these foods, because the

35 International Coastal Cleanup Report, "Together for Our Ocean," Ocean Conservancy, accessed 25 June, 2020, https://oceanconservancy.org/wpcontent/uploads/2017/04/2017-ICC_Report_RM.pdf.

36 Elli Slaughter et al, "Toxicity of Cigarette Butts, and Their Chemical Components, to Marine and Freshwater Fish", Tobacco Control 20 (2011): i25-i29, 10.1136/tc.2010.040170.

37 Moses Ompusunggu, "Study to Challenge Claim Indonesia SecondBiggest Marine Polluter", The Jakarta Post, accessed July 2, 2020, https://www.thejakartapost.com/news/2018/02/23/study-to-challengeclaim-indonesia-second-biggest-marine-polluter.html.

38 The Ocean Cleanup Annual Report 2017, loc.cit.

39 Kementerian Kelautan dan Perikanan, "Produktivitas Perikanan Indonesia," accessed July 3, 2020, https://kkp.go.id/wpcontent/uploads/2018/01/KKP-Dirjen-PDSPKP-FMB-Kominfo-19Januari-2018.pdf. 
seafood contains toxic ingredients such as polychlorinated biphenyls (PCBs) and dichloro diphenyl trichloroethane (DDT). ${ }^{40}$

\section{PREVENTIVE MEASURES NECESSARY FOR THE PROTECTION OF MARINE ECOSYSTEM FROM TOXIC AND HAZARDOUS WASTES UNDER INDONESIAN LAW}

Indonesia, as the world's largest archipelago and a key member of the IMO (International Maritime Organization) and has ratified the IMOproduced International Convention on the Prevention of Pollution from Ships in 1973 and its protocol in 1978, namely the International Convention for the Prevention of Pollution from Ships known as Maritime Pollution (MARPOL) 1973/1978. This convention has been ratified by Indonesia through the Presidential Decree No. 46 of 1986. Under MARPOL 73/78, IMO imposes on flag states to ensure that ships under their flag comply with international environmental regulations ${ }^{41}$, among others with the Annex V of MARPOL 73/78 on prevention of pollution by garbage from ships. The most important feature of this Annex is the complete ban imposed on the dumping into the sea of all forms of plastic.

As a form of protecting marine ecosystems from toxic and hazardous waste, Indonesia has also ratified UNCLOS 1982 (United Nations Convention on The Law of The Sea) with Law Number 17 of 1985 (State Gazette of the Republic of Indonesia of 1983 Number 76; Attachment to the State Gazette of the Republic of Indonesia Number 3319). ${ }^{42}$ Chapter XII of UNCLOS contains special provisions for the

40 Madeleine Smith et al, "Microplastic in Seafood and the Implications for Human Health", Current Environmental Health Reports, 2018, https://www.researchgate.net/

publication/327055943_Microplastics_in_Seafood_and_the_Implication s_for_Human_Health.

41 Kuncowati, "Pentingnya Pemahaman Awak Kapal Mengenai Annex 1 Marpol 1973/1978 dan Latihan Pencegahan Pencemaran Minyak terhadap Penanggulangan Pencemaran Minyak dari Kapal”, Jurnal Saintek Maritim, XVIII (September, 2018): 17-30, http://jurnal.stimartamni.ac.id/index.php/JSTM/article/view/184.

42 Sulistyanto Joko, "Implementasi Konvensi Hukum Laut Internasional 1982 dalam Pembaharuan Undang-undang Perikanan", Jurnal Ilmu 
protection of the marine environment. Article 207 of this Chapter, obliging all states shall adopt laws and regulations to prevent, reduce and control pollution of the marine environment from land-based sources. Therefore, Indonesia considers that the ratification of UNCLOS has an important meaning and role to strengthen Indonesia's position as an archipelagic country in the context of implementing the Archipelago Insight (Wawasan Nusantara). ${ }^{43}$

In addition to preventive measure in law enforcement in the field of protection on the marine ecosystem from toxic and hazardous waste, Indonesian law already enacted regulations concerning on Toxic and Hazardous Waste (in Indonesia is known as Bahan Berbahaya dan Beracun or shorten as B3 waste). The Government Regulation of The Republic of Indonesia Number 74 of 2001 about Management of Hazardous and Toxic Materials is proof that Indonesia has a grave concern on this issue.

The environmental management in Indonesia also refers to the Law Number 32 of 2009 on Environmental Protection and Management (EPM). In the EPM Law, the obligation to manage B3 waste and the duty to obtain permits in B3 waste management is regulated in Article $59(1)^{44}$ and Article 59(4) ${ }^{45}$ of the EPM Law which is an administrative provision in B3 waste management. However, based on the EPM Law, violation of these two provisions are threatened with criminal sanctions as stipulated in Article 103 (for those who produce B3 waste but do not conduct management) and Article 102 (for those who carry out B3 waste management without permission). The EPM law is the latest law which strengthens the criminal sanction; however, the administrative penalty remains the main core in the EPM law.

Administrative law is preventive in nature that aims to enforce laws and regulations before forfeitures arise in both the legal subject
Hukum.
1.
(December,
2014):
$35-43$

https://garuda.ristekbrin.go.id/documents/detail/843778.

43 The onsideration of letter $\mathrm{c}$ of the Law Number 17 of 1985 on Ratification of United Nations Convention on the Law of the Sea.

44 This Article says, "Every person who produces B3 waste is obliged to manage the B3 waste produced".

45 This Article rules "B3 waste management must obtain permission from the Minister, governor, or regent/ mayor in accordance with its authority." 
and the environment. In preventive law enforcement related to B3 waste, active supervision is carried out on potential activities or violations have occurred. From this, it can be understood that administrative law enforcement starts from B3 waste generated from business activities. When a business activity produces B3 waste, it is immediately required to carry out B3 waste management based on the applicable terms and conditions. Provisions and requirements that apply, such as obligations for every business actor or activity that produces B3 waste to manage the waste where the management of B3 waste previously had to obtain permission, are some examples of normative provisions regulated in the domain of administrative law. ${ }^{46}$

Furthermore, there are several regulations that specifically cater for environmental pollution aside from EPM law. As a preventive measure, the government already enacted regulation about waste management in general. Those who violate or intentionally litter the environment without managing the waste well will be punished. Another specific regulation as a preventive measure by the government is the Government Regulation Number 19 of 1999 about marine pollution and damage control. However, marine pollution caused by tobacco waste in the form of cigarette butts has not been found in Indonesian law. Indonesian law which governs the issue of tobacco only focuses on the topic of tax and human health. None of them regulate the issue of tobacco products which are affecting environmental health, especially in marine pollution.

\section{THE EFFECTIVENESS OF INDONESIAN PREVAILING LAW TOWARDS THE ISSUE OF MARINE ECOSYSTEM PROTECTION FROM THE TOXIC AND HAZARDOUS WASTE}

Several regulations are governing the issue of toxic and hazardous waste (B3 waste). However, law enforcement is still weak. It can be seen from the case of a cigarette butt. No specific regulation clearly explains about tobacco waste product. This waste is generally included

46 Siti Sundari Rangkuti, Hukum Lingkungan dan Kebijaksanaan Lingkungan Nasional (Surabaya: Airlangga University Press, 2010), 190192. 
in the type of toxic and hazardous waste. Indonesia is in the process of discussing the draft of tobacco law. It remains a debatable issue. ${ }^{47}$

As mentioned before, Indonesia has also regulated the issue of marine pollution in the Government Regulation No.19 of 1999 concerning Marine Pollution and Marine Damage Control. However, the pollution of the oceans caused by tobacco waste in the form of cigarette butts has not been found in Indonesia regulation. Furthermore, Indonesia has a law on waste management wherein the regulation is specially used for managing the land-based or solid waste.

Although Indonesia has several regulations regarding tobacco products, it is only concerned with human health and customs matter. No provision regulates pollution caused by cigarettes which impact on environmental damage, especially ocean pollution. Laws in Indonesia also have not applied the EPR principle in the Indonesian ecological laws. In fact, this principle will affect the prevention and handling of pollution caused by several companies, especially cigarette companies.

According to Thomas Lindhqvist the concept of EPR is "an environmental policy protection strategy to achieve environmental goals of the total environmental impact of a product, by making product producers responsible for the entire product life cycle and especially for recovery, recycling and disposal end of the product". Additionally, the concept of EPR began in the early 1990s by Thomas Lindhqvist. Based on the definition put forward by Lindhqvist, there are three main purposes contained in EPR, they are:

a. to adopt the environmental costs of products into their retail prices;

b. to divert the economic burden from managing toxicity and other ecological damage correlated with post-consumer waste away from the government regions and taxpayers and turn to producers; and

c. to provide encouragements to producers to include environmental concerns in the design of their products. ${ }^{48}$

47 Anonymous, "Yang Perlu Anda Tahu dari Kontroversi RUU Pertembakauan," BBC News, accessed June 15, 2020, https://www.bbc.com/indonesia/indonesia-39179264 .

48 Clifton Curtis et.al, loc cit. 
EPR-based laws have already been implemented in more than 20 US states, and they are legally binding that require producers of the products which contain toxic or non-environmental friendly materials to be responsible for the management of all important portions of their life cycle, especially for post-consumer waste management. ${ }^{49}$

If Indonesia has a specific rule about tobacco waste product, it will give some benefits to Indonesia. The government could easily impose punishments for those who violate the law, whether they are the tobacco manufacturers, tobacco farmers, or even the smokers themselves. The punishment could be varied based on the level of violation. Another option that can be chosen by the Indonesian government is by including the EPR law concept in all regulations which governs the issue of tobacco. For example, the EPR principle can be included in one of the provisions in the Law Number 39 of 2007 about tobacco custom. If the EPR principle is applied, the company will be responsible not only on the beginning of producing a cigarette, but also until the cigarette is used by the smoker. Normally, the cigarette litter is in the form of cigarette butt which can affect the environment. To resolve the environment problem, the government can make the company responsible by paying taxes for the environmental matter.

\section{POLICY OPTIONS IN REDUCING THE ENVIRONMENTAL IMPACT OF CIGARETTE BUTT LITTER IN INDONESIA}

There are several models for possible action against cigarette butt waste that can be implemented in Indonesia. ${ }^{50}$ These options are listed below.

49 RW Patra, and B Cole, "Toxicity and a Hazard Assessment of Cigarette Butts to Aquatic Organisms," Interact (2002): 25, 10.1136/tc.2010.040170.

50 Thomas E. Novotny et al, "Cigarettes Butts and the Case for an Environmental Policy on Hazardous Cigarette Waste", Int. J. Environ. Res. Public Health 6 (2009): 1691-1705, https://dx.doi.org/10.3390\%2Fijerph6051691. 


\section{Labelling}

Some products have a warning label which prohibits littering, especially for non-biodegradable materials such as plastic. However, this does not apply to cigarette packaging. The packaging label only mentioned that cigarettes are harmful to human health. There is no warning label for smokers from throwing cigarette butts properly. Therefore, to make people aware that cigarettes are also a material that is difficult to be degraded naturally and can damage the environment, labelling is necessary. Labelling on the packaging is essential because the materials of cigarette filters are non-biodegradable which could be categorized as hazardous waste. Thus, disposal of filters or cigarette butts should follow the law.

\section{Waste Tax}

Raising the price of cigarettes is a way that can be used to pay for the additional waste costs imposed by the government on cigarette factories. The other waste costs generated in the form of a cigarette butt can reduce the environmental impact caused by cigarette production. Taxes generated from cigarettes are not only used for human health purposes but also must be used to reduce the environmental effects, and the results of the collection of products produced by the government can be used for research on cigarette butts.

\section{Litigation}

Until now litigation cases against cigarette manufactures only focus on health problems. Health costs caused by cigarette consumption are ultimately paid for by other parties such as insurance companies or even the state. Supposedly, the payment of health costs is borne by cigarette companies. However, the weak regulation in Indonesia regarding the responsibility of cigarette companies makes it a distinct advantage for cigarette companies.

However, the tobacco industries can still be made responsible for the impact of their products. A class action can be done by communities who feel disadvantaged over their products. For example, a coastal community that usually has the voluntary task of cleaning the ocean from garbage is able to file a lawsuit to court asking for 
compensation as a result of the impact caused by a cigarette butt. The impact of the cigarette butt is not entirely the fault of the cigarette manufacturer, because the cigarette butt is the final product produced by smokers, where the responsibility of removing the cigarette butt is entirely on the smokers.

However, cigarette factories can also be ignited because they produce goods that damage the environment, toxic ingredients to make cigarette butts that are very harmful to the environment. Cigarette companies should consider the use of hazardous materials for the environment. In this case, if Indonesia applies the EPR principle in the law, the companies are very firmly responsible for their products, starting from the beginning of production until after being handled by the consumer.

\section{Fines}

Fines imposed due to some violations or smoking bans on beaches could be collected by the local community. Penalties can also be imposed by the state (or city) on cigarette producers, the penalties could be measured based on the amount of cigarette waste which is found. This fine will at least make up for some of the costs of cleaning and disposing of cigarette waste, and they will be forwarded to consumers, thereby increasing the cost of smoking and reducing consumption.

\section{Ban Disposable Filters}

Some products that are known to be dangerous or useless and easily disposed of should be completely prohibited from sales and distribution. For example, pop-tops on aluminium cans that can cause injury to the foot when accidentally stepping on it were regulated by US state laws. Indonesia could follow the United States effort on controlling the disposal problem. Thus, banning filtered cigarette will be an effective way of reducing the cigarette butt waste, because it could be considered as an environmental problem. This policy needs further research on the impact of a cigarette butt to determine its potential individual and population health impact. 


\section{Consumer Education and Responsibility}

The decline of cigarette butts' litter is inseparable from the behaviour of conscious consumers to dispose of their litter properly. However, at this time there are still many smokers who are not aware that their practice of disposing of cigarette shears everywhere has serious adverse effects. In some developed countries, there has been a public community to tackle environmental problems such as Buttouts that focus on a personal ashtray, Earth Resource Foundation which focuses on environmental education and others ${ }^{51}$ It is highly recommended for the Indonesian government to create an environmental community that focuses on tobacco waste. With the existence of strict regulations regarding the responsibility of the tobacco industry in tackling environmental impacts, the public community environment will be possible to be formed with the support of the government and the cigarette industry.

\section{LESSONS TO BE LEARNT FROM SINGAPORE AND AUSTRALIA}

To protect the marine ecosystem from the menaces of cigarette butts waste, Singapore and Australia are two countries that can be used as a reference for Indonesia. As a country with a limited area, Singapore uses an incineration process in managing the waste. Incineration technology was adopted by Singapore due to its limited landfill. Although adopting this technology needs an extensive cost, but the incineration process can reduce the waste volumes by up to 90 per cent. ${ }^{52}$ The incineration process of waste in Singapore has actually been regulated by the Environmental Public Health Act, which states that incineration waste is a type of general waste that can be managed using an incineration process. Based on this regulation, cigarette butt is part of general waste type $\mathrm{D}$, which means special handling is needed due to its toxicity materials contained. Henceforth, the categorization of types of waste that can be carried out in the incineration process is further regulated in the appendix to the regulation.

51 Thomas E. Novotny et al., loc.cit.

52 Lam Charles HK et al, "Use of MSW Ash Incineration: A Review", $\begin{array}{lllll}\text { Sustainability } 2, & \text { no. } \quad 7 \quad \text { (2010): } & \text { 1943-1968, }\end{array}$ https://doi.org/10.3390/su2071943. 
The incineration process begins with the collection of waste which is then sent to the waste collection area, a place that has been arranged to avoid environmental damage caused by the collected waste. After going through the process of collecting and transporting waste, the waste will be burned using a very high temperature that can reach 1,000 Celsius degree. Then, ash and smoke are produced. By using a very complicated scheme, the resulted smoke does not create pollution. Sometimes the smoke is even cleaner than normal air because before the smoke is discharged through the chimney, the smoke has been filtered through a complicated process. Besides, the ash produced is used to build artificial islands. ${ }^{53}$ Utilization of the results of the incineration process is not only used for producing energy, ash is also used by the government in constructing infrastructure. Ash management and utilization of it must be accurate because erroneous usage will be able to turn around polluting the environment since ash produces heavy metals. ${ }^{54}$

Additionally, in Singapore, there is a very specific Article in regulating disposing of cigarette butts waste, namely article 286 of the Criminal Law Reform Act 2019 which states that anyone who drops or discards cigarette butts that can cause a fire or is suspected to cause a fire will incur a prison or fine. This regulation clearly states the prohibition on disposing of cigarette butt waste. This will be very helpful in matters relating to the protection of marine ecosystems. Because the strong existing law in combating cigarette butts waste will also give an impact on the health of the marine ecosystem which is usually polluted by cigarette waste. Furthermore, Singapore also uses the Environmental Public Health Act for littering to regulate the prohibition of littering, especially cigarette butt waste. Where, the fines imposed can reach $\mathbf{S} \$ 10,000$.

Meanwhile, in Australia, the government invested AUD 16 million starting from 2019 to 2025 in order to create the Pacific Ocean Litter Project (POLP). This activity aims to reduce marine plastic

53 Weijian Xue et al, "Municipal Solid Waste Collection Optimization in Singapore." Applied Geography $62 \quad$ (2015): $182-190$, https://doi.org/10.1016/j.apgeog.2015.04.002.

54 Celia García Arenas et al, "High Fire Resistance in Blocks Containing Coal Combustion Fly Ashes and Bottom Ash." Waste Management 31, no. 8 (2011): 1783-1789, https://doi.org/10.1016/j.wasman.2011.03.017. 
waste, one of them is cigarette butt waste. ${ }^{55}$ New South Wales, one of the states in Australia, is a portrait of Australia's accomplishment in dealing with cigarette butts waste. In terms of legislation, the government of New South Wales clearly and expressly regulates cigarette waste with the Protection of the Environment Operations Act 1997 No. 156, Part 5.6A Article 144A. Penalties for violators can reach AUD11,000 if violators throw cigarette butts in a specific condition, the total fire ban condition in Australia. In addition, the government of New South Wales also made several programmes to educate people about the hazards of cigarette butts waste aimed at increasing their awareness. ${ }^{56}$ Concerning the EPR Principle, the New South Wales government circuitously implements the principle by applying The Return and Earn programmes in which the government cooperates with the community and even companies to encourage in the joining of recycle programmes.

\section{CONCLUSION}

Indonesian law to regulate the issue of cigarette butts as a toxic and hazardous waste for protecting the marine ecosystem needs several improvements. Although Indonesia already has regulations dealing with certain issues relating to the use of tobacco, the regulation is confined to its impact to human health and tobacco custom. There is no provision of tobacco law in Indonesia which focuses on environmental issue. In regulating the issue of cigarette butts and tobacco waste products, the government should enact an effective and specific law about tobacco waste product so that the law enforcement of marine pollution caused by cigarette butts can be prevented. There are several ways for improving provision on Indonesian law by including these issue such as labelling, waste tax, litigation, fines, banning disposable filter, and consumer education and responsibility.

55 Department of Agriculture, Water and Environment, "Pacific Ocean Litter", accessed July 14, 2020, https://www.environment.gov.au/marine/international-activities/pacificocean-litter-project.

56 EPA, "South Wales Report 2012-2017," accessed June 18, 2020, www.epa.nsw.gov.au. 
Moreover, the policymakers needs to be concerned with not only with the impact on human health but also the environmental damage caused by a cigarette and cigarette butts. Not only that, the Indonesian government needs to enact regulation focusing on the issue of tobacco waste product affecting the environment by considering the EPR principle as the basis of the law. Indonesia may refer to the Singapore in applying a waste management system by transforming the waste into energy, some technological systems are needed in managing the waste in order to achieve an efficient waste disposal system. Moreover, by referring to Australia, Indonesia may imitate the way Australia formulates specific regulation concerning the issue of cigarette butt waste which aims to protect the marine life. 